\title{
Faktor yang Berhubungan dengan Kejadian Anemia pada Ibu Hamil di Puskesmas Watampone
}

\author{
Musni $^{1}$ \\ 1. Akademi Kebidanan Batari Toja Watampone, Jl. Poros Majang No.17, Kab.Bone, Indonesia, 92711 \\ *e-mail: y_musni@yahoo.com
}

\begin{abstract}
Anemia is a major health problem in developing countries with high levels of morbidity occurred in pregnant women. It is happened to be a potential lost in developing a healthy term infant in first trimester. Several related risk factor in mother such age, parity, nutritional state and antenatal care visit contribute to lower incidence of this case. Thereefore this research aimed to determine whether this four contribute factors most related to prevalence of anemia. The study conducted in local Primary Health Care Clinic in District of Watampone during April - August 2017. Involving 203 pregnant mother selected purposively during antenatal care visit at the same period. Using chi square test to analyses all the related variable (CI 95\%, $p$ value <0.05). Among all four variable the result show that Age ( $p$ value 0.001) and nutritional state during pregnancy ( $p$ value : 0.001) are two most significant compare to other two variable including parity ( $p$ value: 0,011) and antenatal care visit ( $p$ value : 0.013). According to the results of the analysis, it is necessary to monitor the nutritional status specifically at pregnant mothers who spanned the age at high risk, in order to undergo a period of safe conception. as recommendations on clinical prevention services of women of childbearing age, need to improve the promotion of the use of contraceptives for women at that age have not been categorized as safe for pregnant and give birth.
\end{abstract}

Keyword : age, anemia, antenatal care visit, nutritional state, parity, pregnancy.

\begin{abstract}
Abstrak
Anemia adalah masalah kesehatan utama di negara berkembang dengan tingkat morbiditas yang tinggi terjadi pada wanita hamil. Hal ini kebetulan menjadi potensi hilang dalam mengembangkan bayi cukup sehat di trimester pertama. Beberapa faktor risiko terkait pada ibu seperti usia, paritas, status gizi dan kunjungan perawatan antenatal berkontribusi untuk menurunkan insiden kasus ini. Oleh karena itu penelitian ini bertujuan untuk mengetahui apakah keempat faktor yang berkontribusi paling berhubungan dengan prevalensi anemia. Penelitian dilakukan di Klinik Perawatan Kesehatan Primer setempat di Kecamatan Watampone selama bulan April - Agustus 2017. Melibatkan 203 ibu hamil yang dipilih secara purposif selama kunjungan pemeriksaan kehamilan pada periode yang sama. Menggunakan uji chi square untuk menganalisis semua variabel terkait (CI 95\%, nilai $\mathrm{p}<0,05)$. Di antara keempat variabel hasilnya menunjukkan bahwa Umur ( $p$ value 0,001 ) dan status gizi selama kehamilan ( $p$ value: 0,001 ) adalah dua yang paling signifikan dibandingkan dengan dua variabel lainnya termasuk paritas (nilai p: 0,011) dan kunjungan perawatan antenatal (nilai p: 0,013). Menurut hasil analisis, perlu untuk memantau status gizi khusus pada ibu hamil yang membentang usia pada risiko tinggi, untuk menjalani periode konsepsi yang aman. sebagai rekomendasi pada layanan pencegahan klinis wanita usia subur, perlu meningkatkan promosi penggunaan kontrasepsi untuk wanita pada usia tersebut belum dikategorikan aman untuk hamil dan melahirkan.
\end{abstract}

Kata kunci: anemia, kehamilan, kunjungan perawatan antenatal, paritas, status gizi, usia. 


\section{Pendahuluan}

Anemia pada kehamilan merupakan salah satu masalah nasional karena mencerminkan nilai kesejahteraan sosial ekonomi masyarakat dan pengaruhnya sangat besar terhadap kualitas sumber daya manusia. Anemia pada ibu hamil disebut "potensial danger to mother and child" (potensial membahayakan ibu dan anak). Oleh karena itu, anemia memerlukan perhatian serius dari semua pihak yang terkait dalam pelayana kesehatan (Manuaba, 2007).

Anemia pada wanita hamil merupakan problema kesehatan yang dialami oleh wanita di seluruh dunia terutama di negara berkembang. WHO melaporkan bahwa ibu hamil yang mengalami defisiensi besi sekitar 35\% - 75\% serta semakin meningkat seiring dengan pertambahan usia kehamilan (Proverawati, 2011)

Kejadian anemia di dunia menduduki urutan ketiga dengan prevalensi anemia pada ibu hamil 74\%. Prevalensi anemia di Asia bervariasi diantaranya Thailand 39\% dan India 85,5\%. Menurut World Health Organization (WHO) $40 \%$ kematian ibu di negara berkembang berkaitan dengan anemia dalam kehamilan. Menurut laporan hasil Riset Kesehatan Dasar (RISKESDAS) 2013 menunjukkan bahwa prevalensi anemia ibu hamil di Indonesia pada tahun 2013 adalah $37,1 \%$ dan prevalensinya hampir sama antara ibu hamil di perkotaan $(36,4 \%)$ dan pedesaan $(37,8 \%)$. Hal ini menunjukkann angka tersebut mendekati masalah kesehatan masyarakat berat (Severe Public Health Problem) dengan batas prevalensi anemia $\geq 40 \%$ (Riskesdas, 2013).

Anemia dalam kehamilan merupakan masalah kesehatan yang utama di negara berkembang dengan tingkat morbilitas tinggi pada ibu hamil. Rata-rata kehamilan yang disebabkan karena anemia di Asia diperkirakan sebesar 72,6\%. Tingginya prevalensi anemia pada ibu hamil merupakan masalah yang tengah dihadapi pemerintah Indonesia (Adawiyani, 2013).

Penelitian terdahulu menjelaskan bahwa adanya hubungan yang signifikan antara keteraturan ANC dengan kejadian Anemia pada ibu hamil ( Sumi Dwi Antono 2017). Selain itu penelitian sebelumnya juga telah menjelaskan bahwa terdapat hubungan dari segi status gizi ibu hamil dan paritas dengan kejadian anemia dijelaskan bahwa semakin baik status gizi ibu hamil akan memperbaiki sistem dalam tubuh ibu hamil terkhusus sel darah merah yang di dalamnya mengandung hemoglobin

Menurut data Riset Kesehatann Dasar (RISKESDAS) pada tahun 2013, prevalensi anemia gizi ibu hamil di Indonesia sebesar 24,5\%, sedangkan pada profil kesehatan Sulawesi Selatan tahun 2008 menuliskan bahwa terdapat $28,1 \%$ penderita anemia di Sulawesi Selatan. Data hasil kegiatan seksi ibu dan KB Dinas Kesehatan (Dinkes) provinsi Sulawesi Selatan tahun 2010 menunjukkan tujuh kota dengan prevalensi anemia besar tertinggi yaitu Selayar, Bantaeng. Barru, Tator dan Toraja Utara (Riskesdas, 2013).

Berdasarkan data Dinas Kesehatan Kabupaten Bone pada tahun 2015 jumlah ibu hamil yang mengalami anemia sebanyak 4963 orang (32,65\%). Pada tahun 2016 menurun menjadi 2868 orang (18,3\%) dan tahun 2017 ibu hamil yang menderita anemia meningkat yaitu 5.043 orang (33,82\%). (Dinkes. Kab.Bone). Tujuan dalam penelitian untuk melihat Umur, status gizi selama kehamilan paritas, kunjungan perawatan antenatal dengan kejadian anemia pada ibu hamil

\section{Metode}

Jenis penelitian ini adalah analitik dengan desain cross sectional. Penelitian ini dilakukan di Puskesmas Watampone Kabupaten Bone.

Populasi pada penelitian ini adalah ibu hamil yang berkunjung di Puskesmas Biru pada bulan April - Agustus tahun 2017. Teknik pengambilan sampel yang digunakan adalah total sampling yaitu jumlah populasi sama dengan jumlah sampel. Adapun besar sampel pada penelitian ini yaitu 203 ibu hamil.

Data yang digunakan adalah data sekunder. Data mengenai umur, paritas, ANC dan LILA ibu hamil, diperoleh dari buku register Puskesmas Watampone. Dan data anemia pada ibu hamil yang mana diperoleh berdasarkan hasil pemeriksaaan laboratorium yang mengalami penurunan hemoglobin kurang dari nilai normal.

Analisis data yang digunakan program SPSS 18 dengan menggunakan uji Chi-Square dengan tingkat kepercayan $95 \%(\mathrm{p}<0,05)$ untuk melihat hubungan antara dua variabel yaitu variabel dependen dengan variabel independen dengan kriteria. Umur 20-35: tdk beresiko, $<20 \&>35$ : beresiko. Frekuensi ANC tdk beresiko apablila : min 1 kali kunjungan pada trimester 1, 2 kali kunjungan pada trimester 2 dan 4 kali kunjungan pada trimester 3 . Kurang dari kunjungan tsb. Termasuk beresiko. Dikatakan Anemia jika hb pada kehamilan trimester $1 \& 3<11 \mathrm{gr} / \mathrm{dl}, \mathrm{n}$ trimester $2<10.5 \mathrm{gr} / \mathrm{dl}$. normal atau tdk anemia jk hb > 11 untk khmln trimester $1 \& 3, \mathrm{hb}>10.5$ trimester 2 . 


\section{Hasil}

Tabel 1. Hubungan umur dengan anemia pada ibu hamil di puskesmas watampone

\begin{tabular}{|c|c|c|c|c|c|c|c|}
\hline \multirow{3}{*}{ Umur Ibu } & \multicolumn{4}{|c|}{ Kejadian Anemia } & \multirow{2}{*}{\multicolumn{2}{|c|}{ Jumlah }} & \multirow{3}{*}{$\begin{array}{c}P \\
\text { Value }\end{array}$} \\
\hline & \multicolumn{2}{|c|}{ Ya } & \multicolumn{2}{|c|}{ Tidak } & & & \\
\hline & $\mathbf{n}$ & $\%$ & $\mathbf{n}$ & $\%$ & $\mathbf{n}$ & $\%$ & \\
\hline Tidak berisiko & 35 & 17,2 & 138 & 68,0 & 173 & 85,2 & \multirow{2}{*}{0.00} \\
\hline Berisiko & 15 & 7,4 & 15 & 7,4 & 30 & 14,8 & \\
\hline Jumlah & 50 & 24,6 & 153 & 75,4 & 203 & 100 & \\
\hline
\end{tabular}

Berdasarkan tabel 1. Responden tertinggi pada kelompok umur tidak berisiko dan tidak menderita Anemia yaitu 138 orang $(68,0 \%)$ dan pada kelompok umur berisiko yang menderita anemia dan tidak jumlahnya sama yaitu 15 orang $(7,4 \%)$.

Berdasarkan uji statistik nilai $\mathrm{P}=0,00$ berarti signifikan / bermakna yang berarti ada hubungan antara umur dengan kejadian anemia pada ibu hamil.

Tabel 2. Hubungan paritas dengan anemia pada ibu hamil di puskesmas watampone

\begin{tabular}{lccccccc}
\hline \multirow{2}{*}{ Paritas } & \multicolumn{4}{c}{ Kejadian Anemia } & \multirow{2}{*}{ Jumlah } & \multirow{2}{*}{ P } \\
\cline { 2 - 6 } & \multicolumn{2}{c}{ Ya } & \multicolumn{2}{c}{ Tidak } & & & Value \\
\cline { 2 - 6 } & $\mathbf{n}$ & $\mathbf{\%}$ & $\mathbf{n}$ & $\mathbf{\%}$ & $\mathbf{n}$ & $\mathbf{\%}$ & \\
\hline Tidak berisiko & 45 & 22,1 & 150 & 73,9 & 195 & 96,1 & \multirow{2}{*}{0,011} \\
Berisiko & 5 & 2,5 & 3 & 1,5 & 8 & 3,9 & \\
\hline Jumlah & 50 & 24,6 & 153 & 75,4 & 203 & 100 & \\
\hline
\end{tabular}

Berdasarkan tabel 2. Responden paling banyak pada paritas tidak berisiko dan tidak menderita anemia yaitu 150 orang $(73,9 \%)$ dan dan yang paling rendah pada paritas berisiko dan tidak mengalami anemia yaitu 3 orang $(1,5 \%)$.

Berdasarkan hasil uji statistik nilai $\mathrm{P}=0,011$ berarti signifikan / bermakna yang berarti ada hubungan antara paritas dengan kejadian anemia pada ibu hamil.

Tabel 3. Hubungan frekuensi anc dengan anemia pada ibu hamil di puskesmas watampone

\begin{tabular}{|c|c|c|c|c|c|c|c|}
\hline \multirow{3}{*}{ Frekuensi ANC } & \multicolumn{4}{|c|}{ kejadian Anemia } & \multirow{2}{*}{\multicolumn{2}{|c|}{ Jumlah }} & \multirow{3}{*}{$\begin{array}{c}\mathbf{P} \\
\text { Value }\end{array}$} \\
\hline & \multicolumn{2}{|c|}{ Ya } & \multicolumn{2}{|c|}{ Tidak } & & & \\
\hline & $\mathbf{n}$ & $\%$ & $\mathbf{n}$ & $\%$ & $\mathbf{n}$ & $\%$ & \\
\hline Tidak berisiko & 21 & 10,3 & 95 & 46,8 & 116 & 57,1 & 0013 \\
\hline Berisiko & 29 & 14,3 & 58 & 28,6 & 87 & 42,9 & 0,013 \\
\hline Jumlah & 50 & 24,6 & 163 & 75,4 & 203 & 100 & \\
\hline
\end{tabular}

Berdasarkan tabel 3 Responden terendah pada frekuensi ANC tidak berisiko dan mengalami anemia yaitu 21 orang $(10,3 \%)$ dan tertinggi pada responden frekuensi ANC tidak berisiko dan tidak mengalami anemia yaitu 95 orang $(46,8 \%)$.

Berdasarkan uji statistik nilai $\mathrm{P}=0,013$ berarti signifikan / bermakna yang berarti ada hubungan antara frekuensi ANC dengan kejadian anemia pada ibu hamil 
Tabel 4. Hubunga status gizi dengan anemia pada ibu hamil di puskesmas watampone

\begin{tabular}{|c|c|c|c|c|c|c|c|}
\hline \multirow{3}{*}{ Status Gizi } & \multicolumn{4}{|c|}{ Kejadian Anemia } & \multirow{2}{*}{\multicolumn{2}{|c|}{ Jumlah }} & \multirow{3}{*}{$\begin{array}{c}\mathbf{P} \\
\text { Value }\end{array}$} \\
\hline & \multicolumn{2}{|c|}{ Ya } & \multicolumn{2}{|c|}{ Tidak } & & & \\
\hline & $\mathbf{n}$ & $\%$ & $\mathbf{n}$ & $\%$ & $\mathbf{n}$ & $\%$ & \\
\hline Normal & 32 & 15,8 & 130 & 64 & 162 & 79,8 & \\
\hline KEK & 18 & 8,9 & 23 & 11,3 & 41 & 20,2 & 0,001 \\
\hline Jumlah & 50 & 24,7 & 162 & 75,3 & 203 & 100 & \\
\hline
\end{tabular}

Berdasarkan tabel 4. Responden terendah yaitu menderita anemia dengan status gizi KEK yaitu 18 orang $(8,9 \%)$ dan tertinggi pada responden yang tidak menderita anemia dengan status gizi normal yaitu $130(64 \%)$.

Berdasarkan uji statistik nilai $\mathrm{P}=0,001$ berarti signifikan / bermakna yang berarti ada hubungan antara status gizi dengan kejadian anemia pada ibu hamil.

\section{Pembahasan}

1. Hubunganan Umur dengan Anemia pada Ibu Hamil

Umur ibu berhubungan dengan terjadinya anemia pada ibu hamil dimana umur ibu yang kurang dari 20 tahun atau lebih dari 35 tahun cenderung menderita anemia yang lebih besar dibandingkan dengan umur antara 20-35 tahun (Hanifa Wiknjosastro, 2007).

Umur ibu yang ideal dalam kehamilan yaitu pada kelompok umur 20-35 tahun dan pada umur tersebut kurang berisiko komplikasi kehamilan serta memiliki reproduksi yang sehat. Hal ini terkait dengan kondisi biologis dan psikologis dari ibu hamil. Sebaliknya pada kelompok umur $<20$ tahun berisiko anemia sebab pada kelompok umur tersebut perkembangan biologis yaitu reproduksi belum optimal. Selain itu, kehamilan pada kelompok usia di atas 35 tahun merupakan kehamilan yang berisiko tinggi. Wanita hamil dengan umur di atas 35 tahun juga akan renta anemia. Hal ini menyebabkan daya tahan tubuh mulai menurun dan mudah terkena berbagai infeksi selama masa kehamilan (Manuaba, 2007).

Dari hasil analisis uji statistik didapatkan nilai $\mathrm{p}=0,00(\mathrm{p}=<0,05)$ yang berarti bermakna atau signifikan, yang berarti ada pengaruh antara umur ibu dengan anemia pada ibu hamil.

Terjadinya pengaruh yang bermakna ini karena umur $<20$ tahun mempunyai risiko anemia dalam kehamilan karena pada usia tersebut masih membutuhkan zat besi lebih banyak untuk keperluan pertumbuhan diri sendiri serta bayi yang akan dikandungnya. Sementara itu, umur > 35 tahun mempunyai risiko untuk hamil, dimana alat reproduksi ibu hamil sudah menurun dan kekuatan untuk mengejan saat melahirkan sudah berkurang sehinnga anemia pun terjadi pada saat ibu hamil umur $>35$ tahun.

Penelitian ini sejalan dengan penelitian yang dilakukan Willy Astriana di Puskesmas Tanjung Agung Kabupaten Oku pada tahun 2017. yang menyatakan bahwa adanya korelasi antara umur dengan kejadian anemia pada ibu hamil. Penelitia ini tidak sejalan dengan penelitian yang dilakukan Rizqi Ariyani di wilayah kerja Puskesmas Mojolaban Kabupaten Sukoharjo tahun 2016 yang menyatakan bahwa tidak ada pengaruh antara umur ibu dengan kejadian anemia pada ibu hamil.

2. Hubunganan Paritas dengan Anemia pada Ibu Hamil

Paritas adalah jumlah persalinan yang pernah dialami oleh ibu baik lahir hidup maupun lahir mati. Paritas 1-3 merupakan paritas 1 paling aman ditinjau dari sudut kematian maternal. paritas 1 dan paritas tinggi (lebih dari 3) mempunyai angka lebih tinggi. Sebagian kehamilan paritas tinggi adalah kehamilan tidak direncanakan (Sarwono, 2009).

Paritas adalah banyaknya bayi yang dilahirkan seorang ibu, baik melahirkan yang lahir hidup ataupun lahir mati. Risiko ibu mengalami anemia dalam kehamilan salah satu penyebabnya adalah ibu yang sering melahirkan dan pada kehamilan berikutnya ibu kurang memperhatikan asupan nutrisi yang baik dalam kehamilan. Hal ini disebabkan karena dalam masa kehamilan zat gizi akan terbagi untuk ibu dan janin yang dikandung (Herlina, 2009).

Seorang ibu yang sering melahirkan mempunyai risiko mengalami anemia pada kehamilan berikutnya apabila tidak memperhatikan kebutuhan nutrisi, karena selama hamil zat-zat gizi akan berbagi untuk ibu dan janin yang dikandungnya. Semakin sering seorang wanita melahirkan maka semakin besar risiko kehilangan darah dan berdampak pada penurunan kadar Hb. Setiap kali wanita melahirkan, jumlah zat besi yang hilang diperkirakan sebesar $250 \mathrm{mg}$ (Winkjosastro, 2009).

Ibu dengan paritas tinggi mempunyai kecenderungan lebih besar mengalami anemia dibandingkan responden yang paritas rendah. Hal ini dikarenakan pada setiap kehamilan dan persalinan akan terjadi perubahan serabut otot menjadi jaringan ikat pada uterus hal ini dapat menurunkan kemampuan uterus. Paritas 1 keadaan ibu lemah dan 
baru pertama mengalami kehamilan jadi banyak keadaan yang terjadi seperti lemah, kurang nafsu makan, dan khawatir dengan keadaan bayi sehingga kemungkinan dapat terjadinya anemia. Begitu sebaliknya paritas $\geq 3$ fungsi dari alat reproduksi ibu menurun sehingga keadaan ibu lemah, sehingga kejadian anemia menjadi besar

Dari hasil uji analisis statistik nilai $\mathrm{P}=0,011$ berarti signifikan / bermakna yang berarti ada hubungan antara paritas dengan kejadian anemia pada ibu hamil.

Hasil penelitian ini sejalan dengan penelitian Siti Amalia, dkk di Rumah Sakit Bari Palembang yaitu ada hubungan paritas dengan anemia pada ibu hamil. Hasil penelitian ini juga sejalan dengan penelitian Willy Astriana di Puskesmas Tanjung Agung kabupaten Oku dengan nilai p=0,023 yang berarti ada hubungan antara paritas dengan anemia pada ibu hamil

3. Hubunganan Frekuensi ANC dengan Anemia pada Ibu Hamil

Pelayanan ANC merupakan pelayanan yang diberikan pada ibu hamil oleh petugas kesehatan dalam memelihara kehamilannya. Hal ini bertujuan untuk dapat mengidentifikasi dan mengetahui masalah yang timbul selama masa kehamilan. Sehingga kesehatan ibu dan janin akan sehat sampai dengan proses persalian. Pelayanan antenatal care (ANC) dapat dipantau dengan kunjungan ibu hamil dalam memeriksakan kehamilannya. Standar pelayanan kunjungan ibu hamil palinh sedikit 4 kali dengan distribusi 1 kali pada triwulan pertama (K1), 1 kali dalam triwulan kedua (K2), dan 2 kali dalam triwulan ketiga (K3). Pelayanan yang ada di pelayanan antenatal care (ANC) untuk ibu hamil yaitu petugas kesehatan memberikan penyuluhan tentang informasi kehamilan seperti informasi gizi selama hamildan ibu diberi tablet tambah darah secara gratis serta diberikan informasi tablet tambah darah sehingga dapat memperkecil terjadinya anemia selama kehamilan (Depkes RI,2009)

Asuhan antenatal yang efektif menyediakan landasan yang kokoh bagi bidan untuk pertama kali mengkaji kebutuhan ibu dan keluarga. Asuhan tersebut membantu ibu dan professional kesehatan lain merencanakan dan menentukan asuhan yang holistic selama periode kehamilan. Asuhan antenatal yang efektif mendorong terbinanya hubungan positif antara ibu dan professional kesehatan lain, sehingga mereka dapat memberikan kontribusi yang seimbang bagi perawatan ibu dan calon bayinya. Apapun model asuhan yang di berikan bidan, focus asuhan dan perhatian yang utama tetap pada ibu dan bayinya (Holmes, 2011)

Ibu hamil yang rutin memeriksakan kehamilannya akan mendapat konseling tentang kehamilan dan mendapatkan pemberian tablet Fe sehingga dilakukan ANC secara teratur dengan ketaatan konsumsi tablet Fe pada akhirnya akan mencegah terjadinya Anemia.

Berdasarkan uji statistik nilai $\mathrm{P}=0,013$ berarti signifikan / bermakna yang berarti ada hubungan antara frekuensi ANC dengan kejadian anemia pada ibu hamil.

Hasil pada penelitian ini sejalan dengan penelitian Sumi Dwi Antono (2017) di RSUD Nganjuk yaitu ada hubungan yang signifikan antara keteraturan ANC dengan kejadian Anemia pada ibu hamil. Penelitian ini sejalan juga dengan penelitian yang dilakukan Fitra Duhita di Puskesmas Ngoresan Kecamatan Jebres Kota Surakarta tahun 2010 yang menyatakan bahwa ada pengaruh antara frekuensi ANC dengan kejadian anemia pada ibu hamil.

4. Hubunganan Status Gizi dengan Anemia pada Ibu Hamil

Menurut teori yang dikemukakan oleh Departemen Gizi dan Kesehatan Masyarakat (2007), bahwa Anemia sangat dipengaruhi oleh status gizi seseorang. Anemia terutama anemia gizi besi disebabkan karena gizi yang masuk kurang atau tidak adekuat. Penilaian status gizi dibuat untuk mengidentifikasi nutrien yang berperan dalam kasus anemia. Anemia defisiensi besi dapat disebabkan oleh berbagai macam nutrien penting pada pembentukan hemoglobin.

Status gizi yang buruk merupaka factor predisposisi terbesar terjadinya anemia. (Atika) 2009.

Ibu yang memiliki LILA tidak normal sebelum hamil cenderung mengalami anemia dibanding ibu yang meiliki IMT sebelum hamil lebih dari normal tidak mengalami anemia pada kehamilan. Eka Devi Utami (2008)

Berdasarkan uji statistik nilai $\mathrm{P}=0,001$ berarti signifikan / bermakna yang berarti ada hubungan antara status gizi dengan kejadian anemia pada ibu hamil

Hasil penelitian ini sesuai dengan yang dilakukan oleh Ismiatul Ismaini dan Sarwinanti (2016) yang menunjukkan bahwa ada hubungan antara status gizi dengan kejadian anemia

\section{Kesimpulan}

Berdasarkan penelitian yang telah dilakukan dapat disimpulkan bahwa Ada hubungan antara umur, paritas, frekuensi ANC dan status gizi dengan anemia pada ibu hamil di Puskesmas Watampone.

\section{Referensi}

Badan Penelitian dan Pengembangan Kesehatan Kementrian Kesehatan RI. Riset Kesehatan Dasar (Riskesdas 2013). Jakarta; 2013. www.depkes.go.id

Depkes RI. 2009. Profil Kesehatan Indonesia Tahun 2009. Jakarta : Depkes RI. 
Departemen Gizi dan kesehatan Masyarakat FKM UI. (2007). Gizi dan Kesehatan Masyarakat. Jakarta : Raja Grafindo Persada

Herlina, Nina dkk. 2009. Faktor-faktor yang Berhubungan dengan Kejadian Anemi pada Ibu Hamil

Holmes, D. 2011. Ilmu kebidanan. Jakarta: EGC.

Ismiatul Ismaini dan Sarwinanti. (2016). Hubungan Status Gizi dengan Kejadian Anemia pada Ibu Hamil Trimester III di Puskesmas Paliyan Gunungkidul. Universitas aisyiyah Yogyakarta.

Manuaba. 2007. Pengantar Kuliah Obstetri. Jakarta ; EGC

Proverawati Atika. 2009. Buku Ajar Gizi Untuk Kebidanan. Yogyakarta: Nuha Medika

Sarwono, P. 2009. Ilmu Kebidanan. Jakarta : Bina pustaka.

Siti Amallia, Rahmalia Afriyani, Siska Putri Utam. 2017. Faktor Risiko Kejadian Anemia pada Ibu Hamil di Rumah Sakit Bari Palembang. Jurnal Kesehatan, volume 8 No.3

Sumi Dwi Antono. 2017. Hubungan Frekuensi Antenatal care dengan Kejadian Anemia pada Ibu Hamil Trimester III di RSUD Nganjuk tahun 2017. Jurnal Ilmu kesehatan Vol.6. No.1. ejurnaladhkdr.com/index.php

Wiknjosastro, Hanifa. 2007. Ilmu Kebidanan. Jakarta: Yayasan Bina Pustaka Sarwono Prawirohardjo

Winkjosastro. 2009. Ilmu Kandungan Edisi Ke 2 Cetakan ke 4. Jakarta : EGC

Willy Astriana. (2017). Kejadian Anemia Pada Ibu Hamil Ditinjau dari Paritas dan Usia. Jurnal Aisyah : Jurnal Ilmu Kesehatan 2 (2) 